\title{
Can we explain vagrancy in Europe with the autumn migration phenology of Siberian warbler species in East Russia?
}

\author{
László Bozó ${ }^{1 *}$, Wieland HeIM ${ }^{2}$, Andrea Harnos ${ }^{3}$ \& Tibor CsöRGÖ ${ }^{4}$
}

Received: November 16, 2015 -Accepted: February 16, 2016

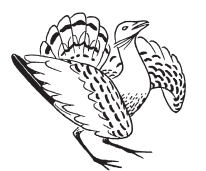

László Bozó, Wieland Heim, Andrea Harnos \& Tibor Csörgő 2016. Can we explain vagrancy in Europe with the autumn migration phenology of Siberian warbler species in East Russia? Ornis Hungarica 24(1): 150-171. Thick-billed Warbler (Iduna aedon), Black-browed Reed Warbler (Acrocephalus bistrigiceps), Pallas's Grasshopper Warbler (Locustella certhiola), Lanceolated Warbler (L. lanceolata), Yellow-browed Warbler (Phylloscopus inornatus), Arctic Warbler (Ph. borealis), Dusky Warbler (Ph. fuscatus), Radde's Warbler (Ph. schwarzi), Two-barred Warbler (Ph. plumbeitarsus) and compared the migration dynamic characteristics with their European occurrence time. The study was carried out within the Amur Bird Project in the Russian Far East along the river Amur at Muraviovka Park between 2011 and 2014. The birds were caught with mistnets and ringed with individually numbered rings. For the characterization of the migration, we used timing, the intervals and the peaks of the migration, the percentage of the recaptures and the average time between the first and the last captures. The timing of migration in the studied species differed in the timing, the intervals (30-67 days) and the migration peaks (14 August - 17 September).

Considering the size and location of the distribution area, the timing and annual patterns of European occurrences, it is likely that most individuals of Thick-billed Warbler, Pallas's Grasshopper Warbler, Dusky Warbler, Radde's Warbler and Two-barred Warbler get to Europe due to the impact of Siberian cyclones. In case of Yellow-browed Warblers, other factors (reverse migration, weather conditions, dispersal movements) may also play a role. Because of their Scandinavian breeding populations, dispersion movement is the most likely reason for vagrants of Arctic Warbler and Lanceolated Warbler. The distribution of the Black-browed Reed Warbler is limited to the eastern edge of the continent, and therefore this species has no European record to date.

Keywords: reverse migration, weather anomalies, dispersion, Muraviovka Park, Siberian Passerines

Összefoglalás Szibériában fészkelő kilenc énekesmadár - vastagcsőrü nádirigó (Iduna aedon), keleti foltos nádiposzáta (Acrocephalus bistrigiceps), csíkos tücsökmadár (Locustella certhiola), foltos tücsökmadár (L. lanceolata), vándorfüzike (Phylloscopus inornatus), északi füzike (Ph. borealis), barna füzike (Ph. fuscatus), vastagcsőrü füzike (Ph. schwarzi), szalagos füzike (Ph. plumbeitarsus) - őszi vonulási fenológiáját vizsgáltuk és összehasonlítottuk öszi vonulásdinamikai jellemzőiket az európai megkerülésük idejével. A vizsgálatokat az Oroszország Amur menti részén elhelyezkedő Muraviovka Parkban végeztük 2011-2014-ben, az őszi vonulás során. A madarakat japán típusú függönyhálókkal fogtuk, és egyedileg számozott gyürủvel jelöltük. A vonulás jellemzésére a vonulás időzitését, intervallumát, csúcsát, a visszafogott madarak százalékát, a befogás és visszafogás közötti átlagos időtartamot használtuk. A vizsgált fajok vonulása különbözött mind az időzítés, mind az intervallum (3067 nap), mind a vonulási csúcs (augusztus 14. - szeptember 17.) vonatkozásában.

Az elterjedési terület méretét és elhelyezkedését, az európai megkerülések idejét és évi mintázatát figyelembe véve a legtöbb vastagcsőrủ nádirigó, csíkos tücsökmadár, barna füzike, vastagcsőrủ füzike, szalagos füzike példány a szibériai ciklonok hatása miatt juthat el Európába. A vándorfüzike esetében minden egyéb tényező (reverz vonulás, időjárási tényezők, nagy diszperziós elmozdulások) szerepet játszhatnak. Az északi füzike és a foltos tücsökmadár skandináviai fészkelóállománya miatt a diszperziós mozgásból eredő megkerülés a legvalószínübb. A keleti foltos nádiposzáta költési areája kicsi és a legkeletebbi előfordulású, valószínüleg ezért nincs európai megkerülése.

Kulcsszavak: reverz vonulás, időjárási anomáliák, diszperzió, Muraviovka Park, szibériai énekesmadarak 
${ }^{1} 5744$ Kevermes, Március 15. utca 4., Hungary, e-mail: bozolaszlo91@gmail.com

${ }^{2}$ Amur Bird Project, Paracelsusstrasse 7., 09114 Chemnitz, Germany

${ }^{3}$ Department of Biomathematics and Informatics, Faculty of Veterinary Sciences, Szent István University,

1078 Budapest, István utca 2., Hungary

${ }^{4}$ Department of Anatomy, Cell- and Developmental Biology, Eötvös Loránd University, 1117 Budapest,

Pázmány Péter sétány 1/c, Hungary

*corresponding author

\section{Introduction}

In the last decades, a significant number of Siberian species appeared in many European countries, and both the number of species and the observations are increasing (Gilroy $\&$ Lees 2003). Possibly the increase in the number of observers in the past decades plays a considerable role. Nevertheless, the question arises, how and why the otherwise mostly in Southeast Asia wintering individuals occur in the opposite or at least very different direction? Answers could include weather anomalies, migration defects (reverse or mirror migration), dispersal movements and changes in the wintering areas (Rabøl 1969, Baker 1977, Folvik 1992, Berthold 1996, Thorup 1998, 2004, Phillips 2000, Elkins 2002, Gilroy \& Lees 2003, Krüger \& Dierschke 2004, Harrup 2007, De Juana 2008, Jiguet \& Barbet-Massin 2013).

The migration of Siberian species which winter in South-South East Asia is less known, we have information only on the autumn migration of some species (Nisbet 1967, Cramp 1992, Marchetti et al. 1995, Halmos et al. 2000, Katti \& Price 2003, Duckworth 2007, Raess 2008). To understand the causes of the European vagrancies, information on migration phenology of this species is needed.

This study aims to describe the migration phenology of nine species: Thick-billed Warbler (Iduna aedon), Black-browed Reed Warbler (Acrocephalus bistrigiceps), Lanceolated Warbler (Locustella lanceolate), Pallas's Grasshopper Warbler (L. certhiola), Yellow-browed Warbler (Phylloscopus inornatus), Arctic Warbler (Ph. borealis), Dusky Warbler (Ph. fuscatus), Radde's Warbler (Ph. schwarzi), Two-barred Warbler (Ph. plumbeitarsus), which migrate in relatively large numbers at Muraviovka Park, and assess the validity of the different vagrancy theories.

The Thick-billed Warbler is a common breeder and abundant migrant in the Muraviovka Park (Heim 2014). Separation of the migratory birds and dispersion of breeding individuals is therefore not possible. The species migrate in one wave within a relatively narrow interval and rather fast. The migration peak is in mid-August. Of the studied species, this one spent the shortest time at the study site. The last individuals were captured in mid-September, by which time the first individuals can arrive to Central China (Williams 2000, Carey et al. 2001). In Beidaihe, which lies nearly halfway on the migration route, app. $800 \mathrm{~km}$ southwest of the Muraviovka Park, this species migrates through from August to mid-October with a peak in mid-September (Williams 2000, Harrop 2007). They reach the northern part of their wintering area between the end of September and end of October (Harrop 2007).

It is a very rare vagrant in Europe, with only six records from Western and Northern Europe (Norway, Great-Britain) since 2001 (www.tarsiger.com), typically between mid-September 


\begin{tabular}{|c|c|c|c|c|}
\hline $\begin{array}{l}\frac{y}{\tilde{J}} \\
\frac{\tilde{\nu}}{n}\end{array}$ & 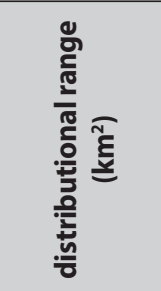 & 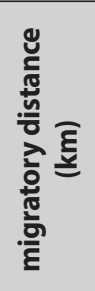 & 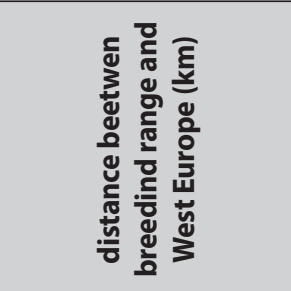 & 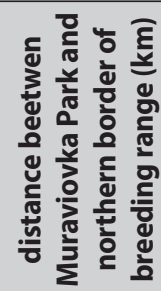 \\
\hline Thick-billed Warbler & $2,670,000$ & 2000 & 5000 & 800 \\
\hline Black-browed Reed Warbler & $2,320,000$ & 1500 & 5000 & 600 \\
\hline Pallas's Grasshopper Warbler & $1,620,000$ & 2000 & 5000 & 1500 \\
\hline Lanceolated Warbler & $2,960,000$ & 2500 & $\begin{array}{l}\text { breeding population } \\
\text { in Skandinavia }\end{array}$ & 2000 \\
\hline Yellow-browed Warbler & $11,000,000$ & 3000 & 2500 & 2000 \\
\hline Artic Warbler & $3,360,000$ & 2500 & $\begin{array}{l}\text { breeding population } \\
\text { in Skandinavia }\end{array}$ & 2000 \\
\hline Dusky Warbler & $3,830,000$ & 2000 & 2000 & 1500 \\
\hline Radde's Warbler & $1,170,000$ & 2500 & 4000 & 500 \\
\hline Two-barred Warbler & $4,640,000$ & 2500 & 6000 & 1000 \\
\hline
\end{tabular}

Table 1. The size of the breeding area, the avarage migration distance and the distance between the breeding area and W-Europe, as well as the distance between breeding area and wintering sites (BirdLife International 2013)

1. táblázat Az egyes fajok fészkelőterületének mérete, átlagos vonulási távolsága, az area távolsága Nyugat-Európa és a telelőterületek közt (BirdLife International 2013)

and mid-October (Harrop 2007). This covers approximately the second half / end of the migration period of the species. The western border of its distribution area lies $5000 \mathrm{~km}$ from Western Europe, which is much more than the average migration distance (Table 1). Thus, it seems likely that Thick-billed Warblers could appear in Europe mainly because of weather anomalies.

The Black-browed Reed Warbler is one of the most abundant breeding birds at Muraviovka Park, and a common migrant as well (Heim 2014). It has only some long-term recaptures from the first part of the study period. These individuals should be local breeders. The western border of the breeding area is app. $5000 \mathrm{~km}$ away from Western Europe. The length of the migration route is the shortest of the studied species (Table 1). There is no European record.

The Pallas's Grasshopper Warbler is an abundant breeder and a common migrant in Muraviovka Park (Heim 2014). The species migrate in a month and a half interval. The migration peak is in mid-August. The migration is fast, with only few and short-term recaptures, despite the fact that the study site is on the southern part of the breeding area, so the northern birds have to migrate $1500 \mathrm{~km}$ to reach this site. The last individuals were captured in mid-September. By this time, the first individuals can arrive to the wintering area in Malaysia (Nisbet 1967). In Europe, this species appears in small numbers between the beginning of September and the end of October (www.tarsiger.com, www.netfugl.dk), which coincides with the arrival to the wintering area. These individuals can thus be reverse migrants, 
however, the distance between the breeding and wintering areas $(2000 \mathrm{~km})$ is much less than the distance between the breeding area and Europe $(5000 \mathrm{~km})$ (Table 1). This reduces the possibility of reverse migration and predicts that Pallas's Grasshopper Warblers reach Europe due to weather anomalies.

The Lanceolated Warbler is a common breeder and regular migrant at Muraviovka Park (Heim 2014), although only few individuals were captured. Birds captured at the beginning of the study period most likely belong to the local population. Migration begins between mid-August and the beginning of October and peaks at the beginning of September. Only few individuals were trapped at the study site, which spent only a short time here, despite the distance between the northern border of the breeding area and Muraviovka Park being around $2000 \mathrm{~km}$. At Beidaihe, this species can be observed from August to mid-October with a peak in the end of September (Williams 2000, Harrop 2007). Here, only migrants and no local breeders occur, which could explain the narrower interval of observation than at the Park. They arrive to Hong Kong in the northern part of their wintering area in October (Harrop 2007). The first individuals arrive to the Malay Penninsula during the beginning of October (Nisbet 1967). In Europe, it is a rare vagrant between the beginning of September and the end of October (Hudson \& the Rarities Committee 2007, 2008, 2009, 2010, 2011, Rogers \& the Rarities Committee 2001, 2002, 2003, 2004, www.tarsiger.com).

The northwestern edge of its distribution area extends into Europe (BirdLife International 2013). In Finland, 20 singing males were observed in 2000 and in the same year, one week before its earliest occurrence ever, the species appeared on $1^{\text {st }}$ of September in Shetland (Rogers \& the Rarities Committee 2000). Concidering the species' distribution area and migration dynamics, some individuals could get to Europe from Siberia by reverse migration and weather anomalies, but some most likely originate from the European population.

The Yellow-browed Warbler is not a breeder, but an abundant migrant at Muraviovka Park (Heim et al. 2012, Heim \& Smirenski 2013). It migrates in a broad interval, covering almost two months. Only few individulas stay for a short time at the study site, despite the northern border of the breeding area being $2000 \mathrm{~km}$ from Muraviovka Park. It has the largest distribution area among the studied species: 2.4 times higher than the second largest and 9.4 times higher than the smallest (Table 1). The migration peak is at the beginning of September.

In Beidaihe it occurs between mid-September and the end of October (Williams 2000, Harrop 2007), while in Hong Kong, which is the northern part of the wintering area, it arrives during mid-September (Harrop 2007). The first half of its migration to Hongkong and Beidaihe overlaps with its occurence in Europe.

Of the Siberian species, the Yellow-browed Warbler is the most commonly recorded in Europe. Some authors explain this with weather factors (Williamson 1959, Baker 1977, Howey \& Bell 1985, Baker \& Catley 1987, Elkins 1988), whereas others with genetic defects (birds are misorientated, defective ones, mirror migration) (Rabøl 1969, 1986, De Sante 1983, Thorup 1998, 2004), or with the establishment of a new wintering area (De Juana 2008).

Furthermore, it has the largest distribution area of the studied species (BirdLife International 2013). The distance between the wintering and breeding areas $(3000 \mathrm{~km})$ is only a little more than the distance to Western Europe $(2500 \mathrm{~km})$. In some years, there are mass migrations not only in Western and Northern Europe, but also even further south, for example 
in the Carpathian Basin (Hadarics \& Zalai 2008, www.birding.hu, www. rombird.ro) and in the Mediterranean (De Juana 2008). The westernmost record comes from Senegal (De Juana 2008).

In Northern and Western Europe, this species occurrs typically between mid-September and mid-November, with a peak in mid-October (Harrop 2007). The number of spring records is much lower - for example, in Germany, this rate is 40:1 (Krüger \& Dierschke 2004). These individuals must be successful wintering survivors (Dymond et al. 1989). It appears earliest in Finland, Sweden and Denmark, then two weeks later in the Netherlands and the United Kingdom. In the latter country, there is a difference between the Northeastern Scottish and southern English areas, and the north of Sweden experiences their arrival one week earlier than the south of the country (Baker \& Catly 1987, Marchant 2002). The number of observed individuals grows in time southward (De Juana 2008).

The temporal pattern of European observations render reverse migration probable, however, the large differences in the number of individuals can be explained by annual weather anomalies (for example in Finland, it had only 79 records in 2010, while in 2011, it had 230 records) (www.tarsiger.com). Individuals might reach Europe from the north-western part of their breeding area during dispersal movements, but it could also reflect different success on the breeding areas: if the species has a good breeding success in a given year, it can occur in larger numbers in Europe.

The Arctic Warbler is a common migrant at Muraviovka Park (Heim 2014). It migrates in a narrow, one month interval between the beginning of August and mid-September. The migration peak is in the second half of August. The northern border of the breeding area is $2000 \mathrm{~km}$ north of the Park (Table 1), but only a few individulas spend a short time in the study site.

It occurs in Western Europe primarily in September (www.tarsiger.com). There is a significant breeding population in Scandinavia, so some of the European occurrences could originate from dispersion movements. The European occurrences do not show large annual differences (Rogers \& the Rarities Committee 2000, 2001, 2002, 2003, 2004, Fraser et al. 2005, 2006, Hudson \& the Rarities Committee 2007, 2008, 2009, 2010, 2011), so they are probably not the consequences of weather anomalies, but of stable dispersal movements.

The Dusky Warbler is a common breeder and migrant at Muraviovka Park (Heim \& Smirenski 2013, Heim 2014). It shows a protracted migration from July to the first part of October, however, breeding birds and migrants cannot be separated. This might explain the long interval, which is three times longer than that of the Two-barred Warbler. The migration peaks in the second half of September. The birds spent longer time at the study site than the other studied species, and their migration is the slowest.

In Beidaihe, it occurs in October (Williams 2000, Harrop 2007). Since there are not local breeders there, the observation interval is narrower than at the Muraviovka Park. Hong Kong, which is the northern part of the wintering area, is reached by migrating birds by the second half of October (Harrop 2007).

In the British Islands, this species is most common from mid-October to mid-November (Harrop 2007). Records from Central and Eastern Europe are between September and February. Most of the European records are from the migration peak, but in some cases, 
individuals were also trapped after this period (Rogers \& the Rarities Committee 2001, 2002, 2003, 2004, www.tarsiger.com). The specific European observation times overlap with the arrival times to the wintering sites. The distance between the wintering sites and the breeding area is comparable to the distance between the western border of the area and Europe (app. $2000 \mathrm{~km}$ ) (Table 1), which makes reverse migration a possible explanation for the occurrences of vagrants. However, the role of weather factors is more probable, since there is a high variation in the annual number of records in Europe (Rogers \& the Rarities Committee 2000, 2001, 2002, 2003, 2004, Fraser et al. 2005, 2006, Hudson \& the Rarities Committee 2007, 2008, 2009, 2010, 2011, www.tarsiger.com).

The Radde's Warbler is a regular migrant and rare breeder at Muraviovka Park (Heim et al. 2012, Heim 2014). It migrates in a reatively narrow interval from the second part of August to the second part of September. The migration peak is in mid-September. The northern border of the breeding area is the closest to the Park among the studied species (Table 3). In Beidaihe, it occured from the end of September to mid-October (Williams 2000, Harrop 2007). Hong Kong, which is the northern part of the wintering area, is reached from the last week of October to the third week of November (Harrop 2007). In Europe, it occurs typically in October (Harrop 2007) as a rare vagrant, primarily in the northern and western countries (Rogers \& the Rarities Committee 2001, 2002, 2003, 2004, www.tarsiger.com). The low number of records might be explained by the long distance between the breeding area and Europe. The number of observed birds shows annual variability in Great Britain (Rogers \& the Rarities Committee 2000, 2001, 2002, 2003, 2004, Fraser et al. 2005, 2006, Hudson \& the Rarities Committee 2007, 2008, 2009, 2010, 2011), which strengthens the weather hypothesis.

The Two-barred Warbler is a regular migrant at Murviovka Park (Heim 2014). It migrates in a narrow interval from mid-August to the beginning of September. The migration peak is in the end of August. The migration is fast, the individuals spent only a short time at the study site.

In Beidaihe, it migrates from September to October, the peak is in mid-October (Williams 2000, Harrop 2007). It arrives to the northern part of the wintering area in the end of September, the peak is in the end of October (Harrop 2007).

In Europe it is a very rare vagrant from mid-September to the end of October (Harrop 2007). It is one of the rarest vagrants, until 2013 it had only 14 European records between the end of September to the end of November in the western and northern countries (www. tarsiger.com). It has the largest distribution area of all studied species, however, the distance between the breeding area and Europe is the longest (Table 1). The low numbers of records might be explained by weather anomalies.

\section{Methods}

The study was carried out during the autumn migrations in 2011-2014 at Muraviovka Park along the middle stream of the Amur River in the Russian Far East. The study site is located $60 \mathrm{~km}$ southeast of the city of Blagoveshchensk (Map 1). 


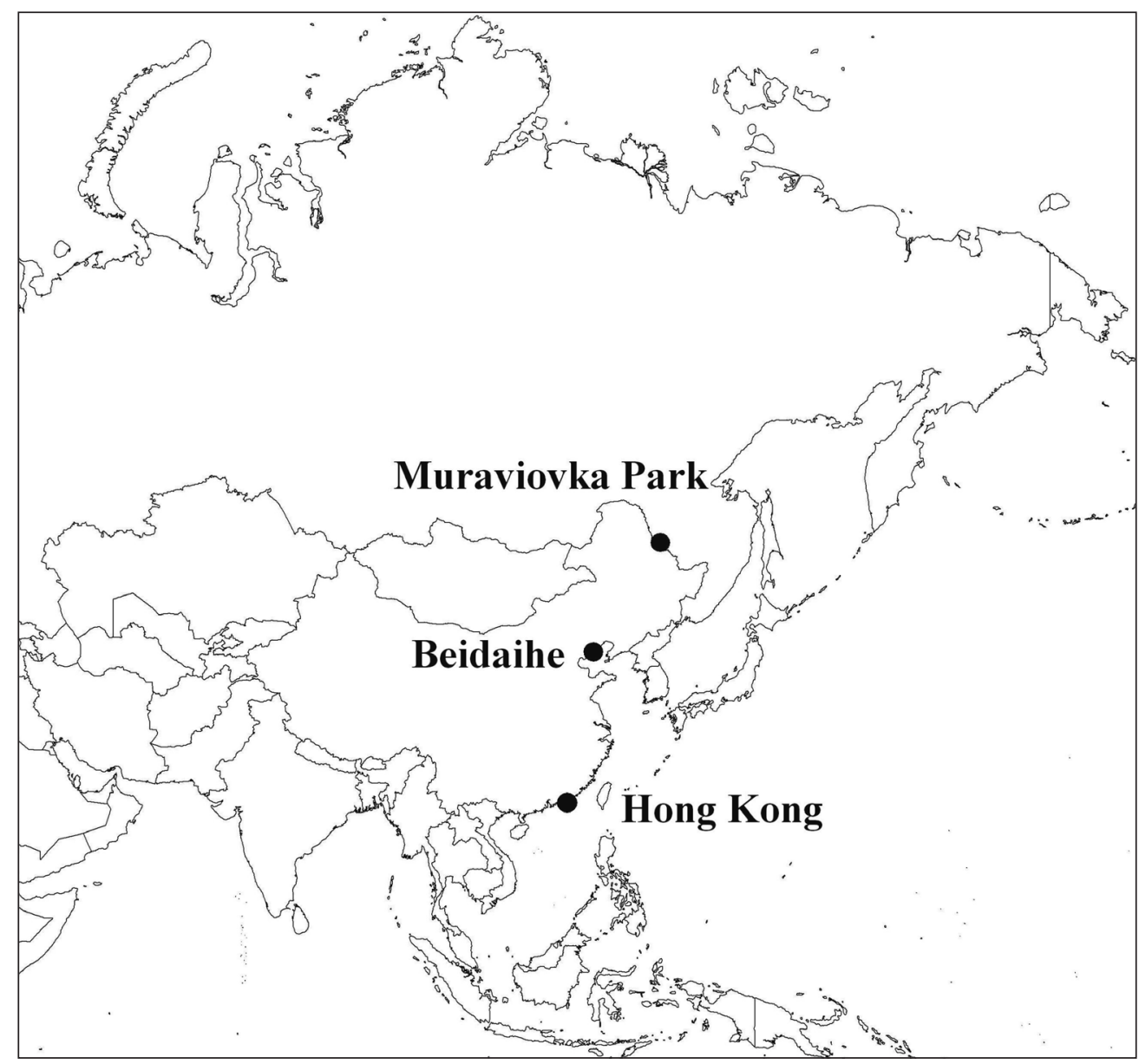

Map 1. The ringing places of the studied species in East-Asia 1. térkép A vizsgált fajok gyűrűzési helyei Kelet-Ázsiában

Up to 34 mist nets (12 and 6 meters in length with 5 packets) were set up in a variety of habitats: homogeneous reed beds, sedges and grassy swamps interspersed with willows and raspberries, rich shrub-layered mixed forest, very dense scrub and stubble. The work was carried out from sunrise to sunset and the nets were checked every hour. The nets were controlled also during the night in 2014.

The study periods were the following: in 2011 , from $7^{\text {th }}$ September to $24^{\text {th }}$ October; in 2012, from $29^{\text {th }}$ August to $16^{\text {th }}$ November; in 2013 , from $25^{\text {th }}$ July to $23^{\text {rd }}$ October, while in 2014, from $25^{\text {th }}$ July to $29^{\text {th }}$ September. In 2011 and 2012, the work began later due to financial reasons, while in 2013, the Amur flooded, which had a strong impact on the work.

For the calculations, we used the earliest common starting date of all years ( $\left.25^{\text {th }} \mathrm{July}\right)$.

The data analysis was carried out based on 5256 individuals of the nine species. Rings were supplied by the Moscow Ringing Centre. Identification of the species was based on Svensson (1992) and Brazil (2009). 


\begin{tabular}{|l|c|c|}
\hline \multicolumn{1}{|c|}{ species } & captures (n) & recaptures (n) \\
\hline Thick-billed Warbler & 628 & 82 \\
\hline Black-browed Reed Warbler & 353 & 25 \\
\hline Pallas's Grasshopper Warbler & 341 & 56 \\
\hline Lanceolated Warbler & 100 & 13 \\
\hline Yellow-browed Warbler & 1580 & 123 \\
\hline Artic Warbler & 122 & 14 \\
\hline Dusky Warbler & 1107 & 347 \\
\hline Radde's Warbler & 217 & 30 \\
\hline Two-barred Warbler & 98 & 20 \\
\hline
\end{tabular}

Table 2. Number of studied species

2. táblázat A vizsgált fajok egyedszáma

We pooled the daily trapping data of the four years and fittedkernel smoothed arrival distribution curves. Subsequently we determined the migration period for each species (the first and last day when the species was captured) and the location of the maximum value as the peak of the smoothed migration curve. We also calculated the percentage of recaptures and the stop-over timing.

All statistical analyses and graphs were made by the $\mathrm{R}$ 3.2.2 program (R Development Core Team 2015) and the smoothed curves were fitted by the "mgcv" package (Wood 2006).

\section{Results}

\section{Thick-billed Warbler}

Of all the studied species, this one was the third most abundant with 628 ringed individuals (Table 2). The migration took place between the $1^{\text {st }}$ and the $55^{\text {th }}$ day. The peak of the migration wave was on the $21^{\text {st }}$ day. Of the ringed birds, $13.1 \%$ have been recaptured, $65.9 \%$ within two days. An average of 2.7 days elapsed between the first and last capture, only one bird was re-trapped after one week (Figure 1, Table 3).

\begin{tabular}{|l|c|c|c|}
\hline \multicolumn{1}{|c|}{ species } & interval & length (day) & peak \\
\hline Thick-billed Warbler & 25 July - 17 Sept. & 55 & 14 Aug. \\
\hline Black-browed Reed Warbler & 25 July - 29 Sept. & 67 & 15 Aug. \\
\hline Pallas's Grasshopper Warbler & 25 July - 21 Sept. & 59 & 15 Aug. \\
\hline Lanceolated Warbler & 27 July - 5 Oct. & 71 & 3 Sept. \\
\hline Yellow-browed Warbler & 26 July - 13 Oct. & 80 & 3 Sept. \\
\hline Artic Warbler & 1 Aug. - 17 Sept. & 48 & 22 Aug. \\
\hline Dusky Warbler & 25 July - 11 Oct. & 79 & 17 Sept. \\
\hline Radde's Warbler & 5 Aug. - 26 Sept. & 49 & 11 Sept. \\
\hline Two-barred Warbler & 4 Aug. - 29 Sept. & 57 & 23 Aug. \\
\hline
\end{tabular}

Table 3. Characteristics of the migration of the studied species

3. táblázat A vizsgált fajok vonulásának jellemzői 


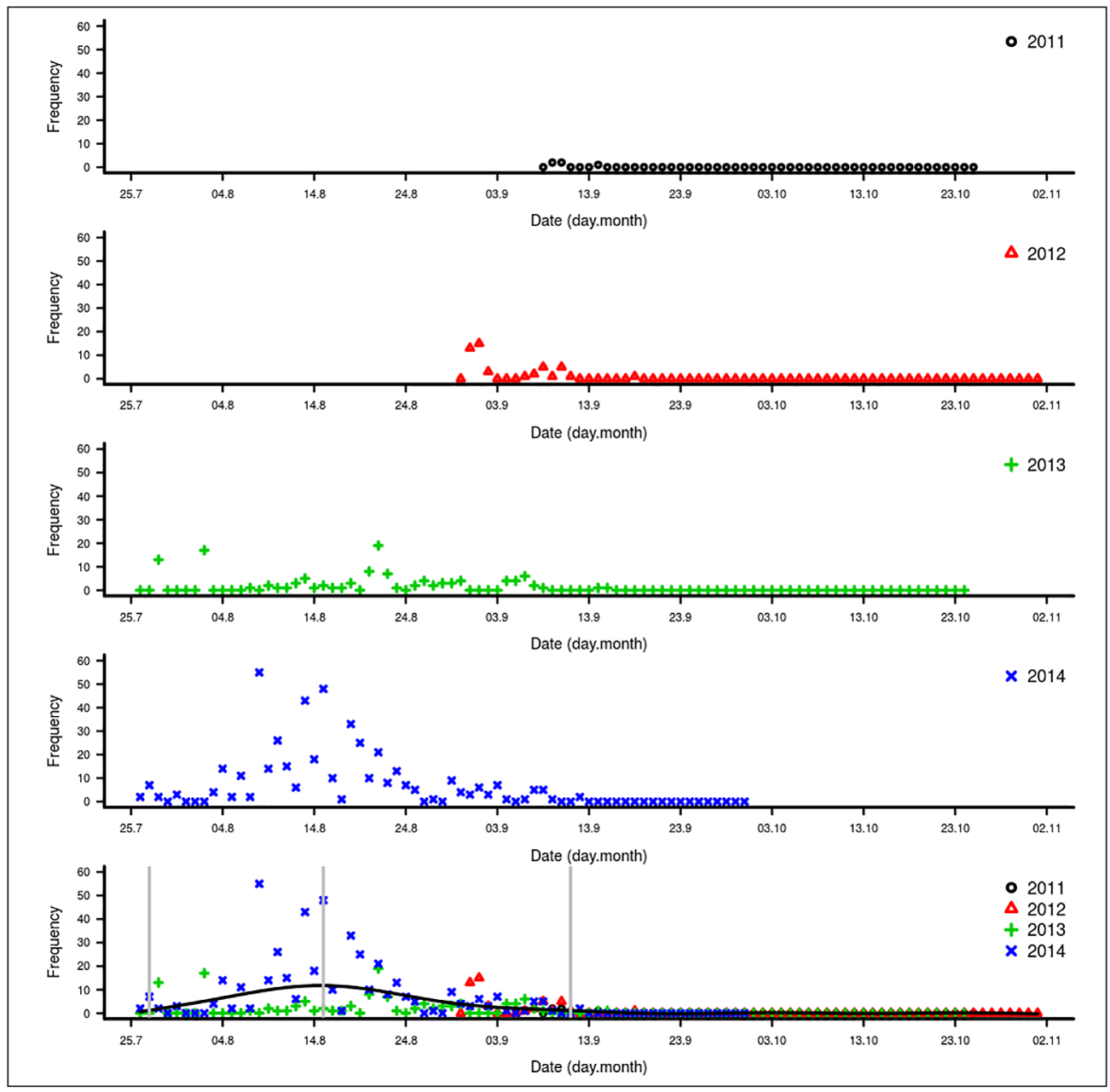

Figure 1. Daily number of ringed Thick-billed Warbler annually and pooled with the fitted smoothed curve. The vertical grey lines show the first, peak and last captures

1. ábra A gyűrűzött vastagcsőrű nádirigó napi gyakorisága éves bontásban és egyesítve a simított görbével. A függőleges szürke vonalak az első, a maximális és az utolsó megfogást mutatják

\section{Black-browed Reed Warbler}

The fifth most abundant species with 353 ringed individuals (Table 2). The migration took place between the $1^{\text {st }}$ and the $67^{\text {th }}$ day. The peak of the migration wave was on the $22^{\text {nd }}$ day. Of the ringed birds, $7.1 \%$ have been recaptured, $48 \%$ within two days. An average of 4.5 days elapsed between the first and last capture, only five birds were re-trapped after one week (Figure 2, Table 3). 


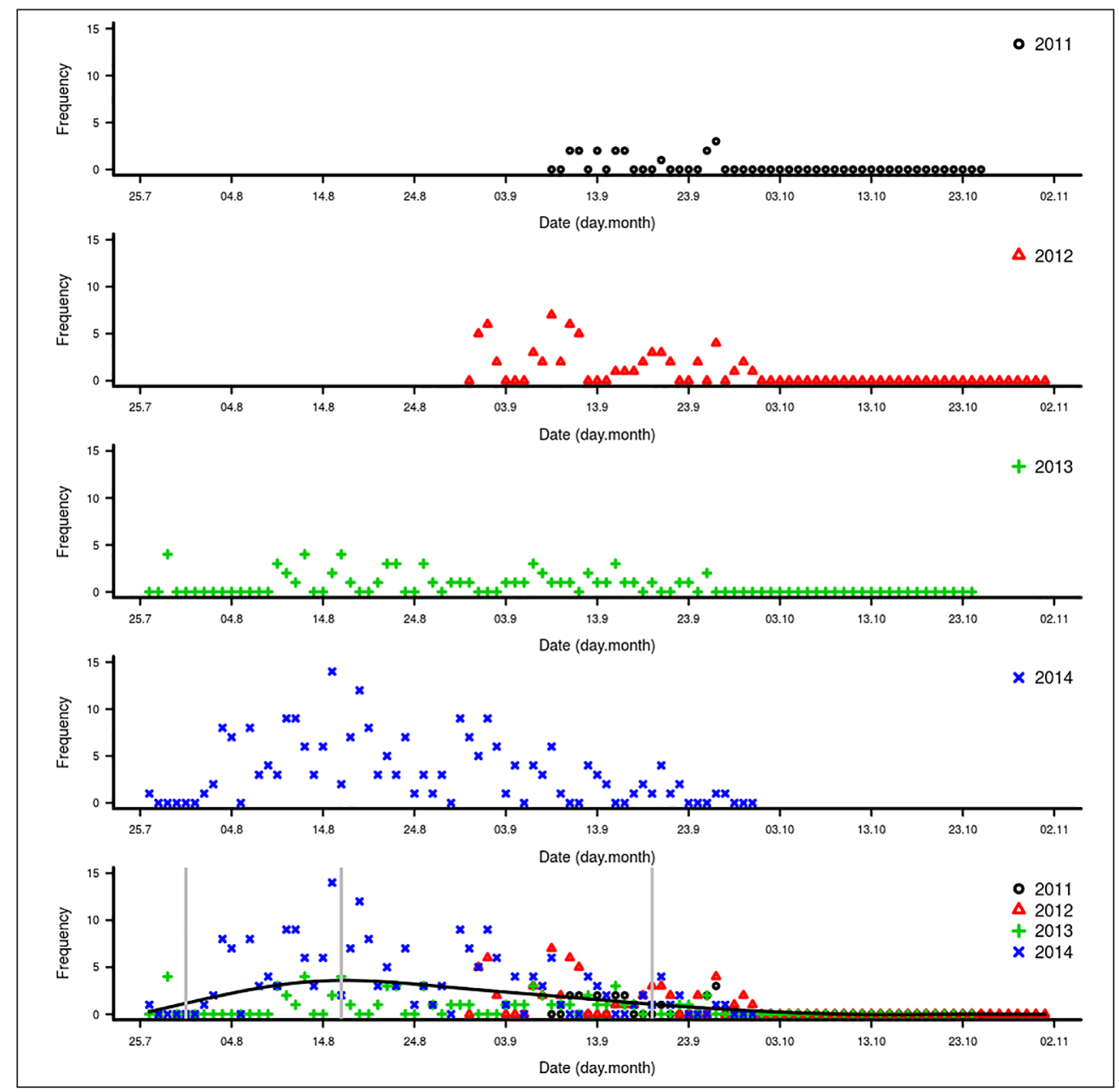

Figure 2. Daily number of ringed Black-browed Reed Warbler annually and pooled with the fitted smoothed curve. The vertical grey lines show the first, peak and last captures

2. ábra A gyűrűzött keleti foltos nádiposzáta napi gyakorisága éves bontásban és egyesítve a simított görbével. A függőleges szürke vonalak az első, a maximális és az utolsó megfogást mutatják

\section{Pallas's Grasshopper Warbler}

The fourth most abundant species with 341 ringed individuals (Table 2). The migration took place between the $1^{\text {st }}$ and the $59^{\text {th }}$ day. The peak of the migration wave was on the $22^{\text {nd }}$ day. Of the ringed birds, $16.4 \%$ have been recaptured, $39 \%$ within two days. An average of 5.4 days elapsed between the first and last capture, 17 birds were retrapped after one week (Figure 3, Table 3). 


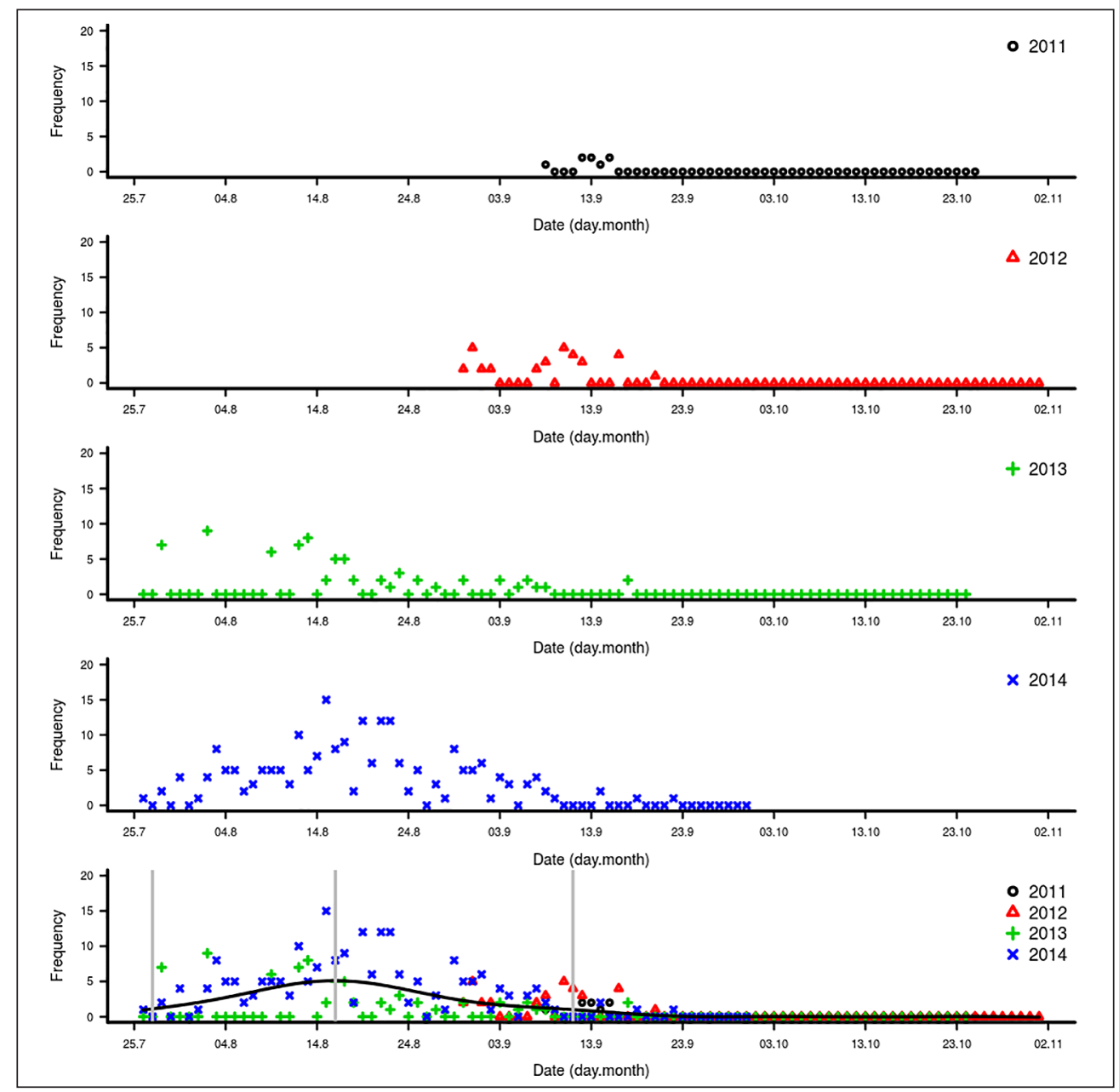

Figure 3. Daily number of ringed Pallas's Grasshopper Warbler annually and pooled with the fitted smoothed curve. The vertical grey lines show the first, peak and last captures

3. ábra A gyűrűzött csíkos tücsökmadár napi gyakorisága éves bontásban és egyesítve a simított görbével. A függőleges szürke vonalak az első, a maximális és az utolsó megfogást mutatják

\section{Lanceolated Warbler}

The eighth most abundant species with 100 ringed individuals (Table 2). The migration took place between the $3^{\text {rd }}$ and the $73^{\text {th }}$ day. The peak of the migration wave was on the $41^{\text {st }}$ day. Of the ringed birds, $13 \%$ have been recaptured, $23 \%$ within two days. An average of 8.5 days elapsed between the first and last capture, only seven birds were re-trapped after one week. One bird was recaptured one year and five days after the first capture (Figure 4, Table 3). 


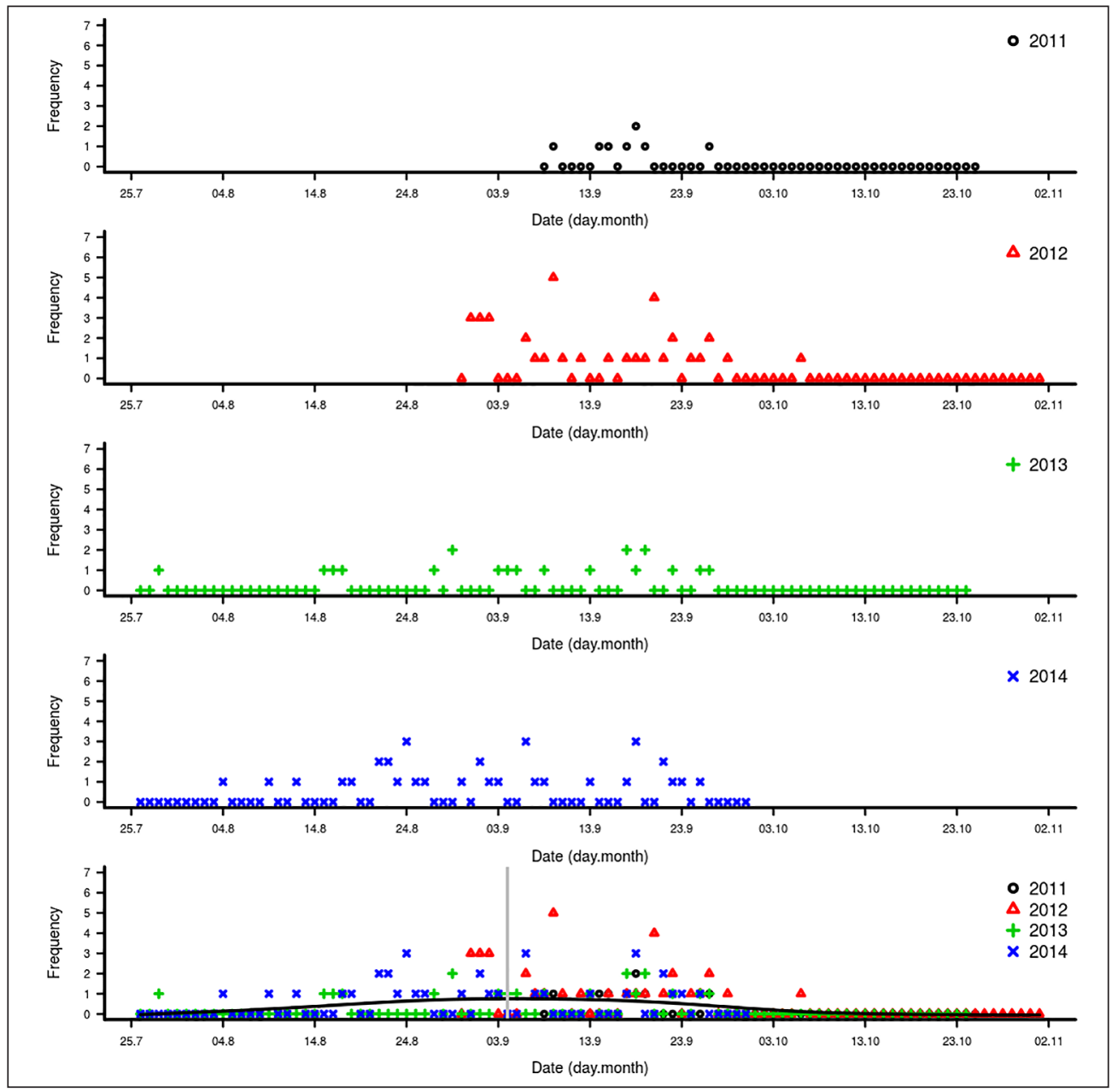

Figure 4. Daily number of ringed Lanceolated Warbler annually and pooled with the fitted smoothed curve. The vertical grey lines show the first, peak and last capture.

4. ábra A gyürűzött foltos tücsökmadár napi gyakorisága éves bontásban és egyesítve a simított görbével. A függőleges szürke vonalak az első, a maximális és az utolsó megfogást mutatják

\section{Yellow-browed Warbler}

Of all the studied species, this one was caught in the highest numbers with 1580 ringed individuals (Table 2). The migration took place between the $2^{\text {nd }}$ and $81^{\text {st }}$ days. The peak of the migration wave was on the $41^{\text {nd }}$ day. Of the ringed birds, $7.8 \%$ have been recaptured, $67.5 \%$ within two days. An average of 2.8 days elapsed between the first and last capture, only seven birds were retrapped after one week (Figure 5, Table 3). 


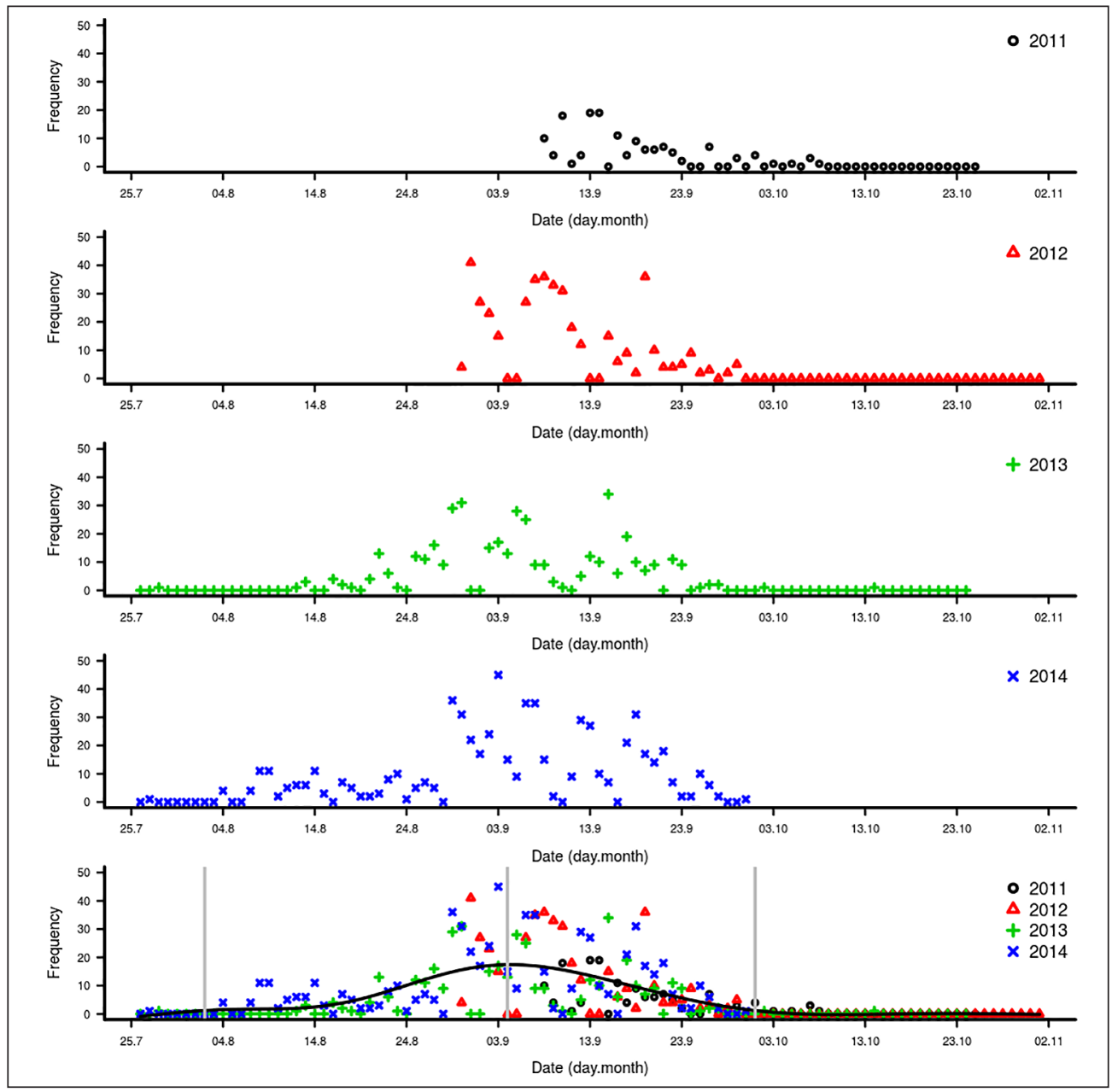

Figure 5. Daily number of ringed Yellow-browed Warbler annually and pooled with the fitted smoothed curve. The vertical grey lines show the first, peak and last captures

5. ábra A gyűrűzött vándorfüzike napi gyakorisága éves bontásban és egyesítve a simított görbével. A függőleges szürke vonalak az első, a maximális és az utolsó megfogást mutatják

\section{Arctic Warbler}

The seventh most abundant species with 122 ringed individuals (Table 2). The migration took place between the $8^{\text {th }}$ and $55^{\text {th }}$ days. The peak of the migration wave was on the $29^{\text {th }}$ day. Of the ringed birds, $11.5 \%$ have been recaptured, $78.5 \%$ within two days. An average of 2.8 days elapsed between the first and last capture, only two birds were retrapped after one week (Figure 6, Table 3). 


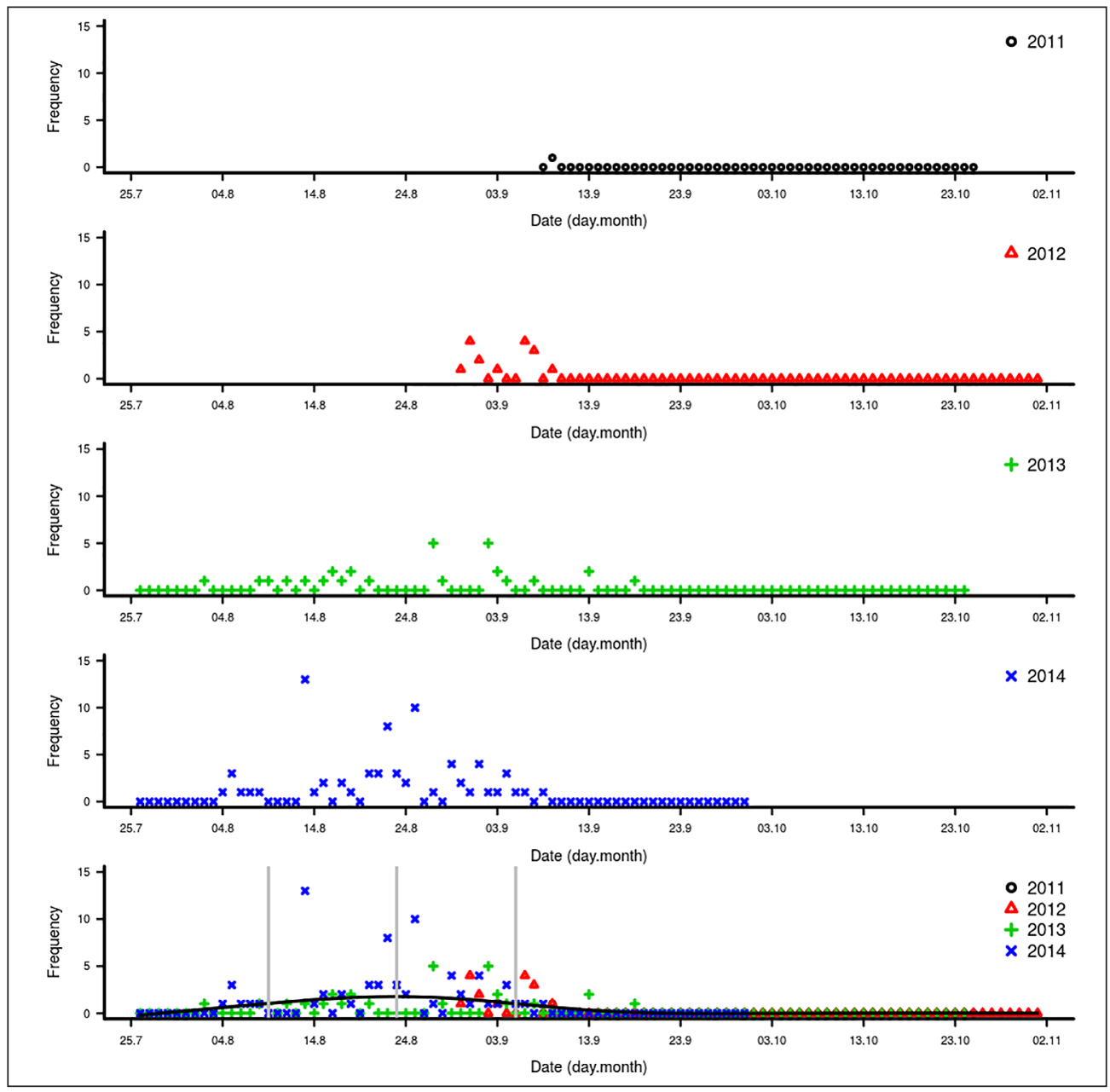

Figure 6. Daily number of ringed Artic Warbler annually and pooled with the fitted smoothed curve. The vertical grey lines show the first, peak and last captures

6. ábra A gyűrűzött északi füzike napi gyakorisága éves bontásban és egyesítve a simított görbével. A függőleges szürke vonalak az első, a maximális és az utolsó megfogást mutatják

\section{Dusky Warbler}

The second most abundant species with 1107 ringed individuals (Table 2). The migration took place between the $1^{\text {st }}$ and $79^{\text {th }}$ days. The peak of the migration wave was on the $55^{\text {th }}$ day. Of the ringed birds, $31.3 \%$ have been recaptured, $35.2 \%$ within two days. An average of 6.4 days elapsed between the first and last capture, 96 birds were retrapped after one week and have three one year and one two years recaptures (Figure 7, Table 3). 


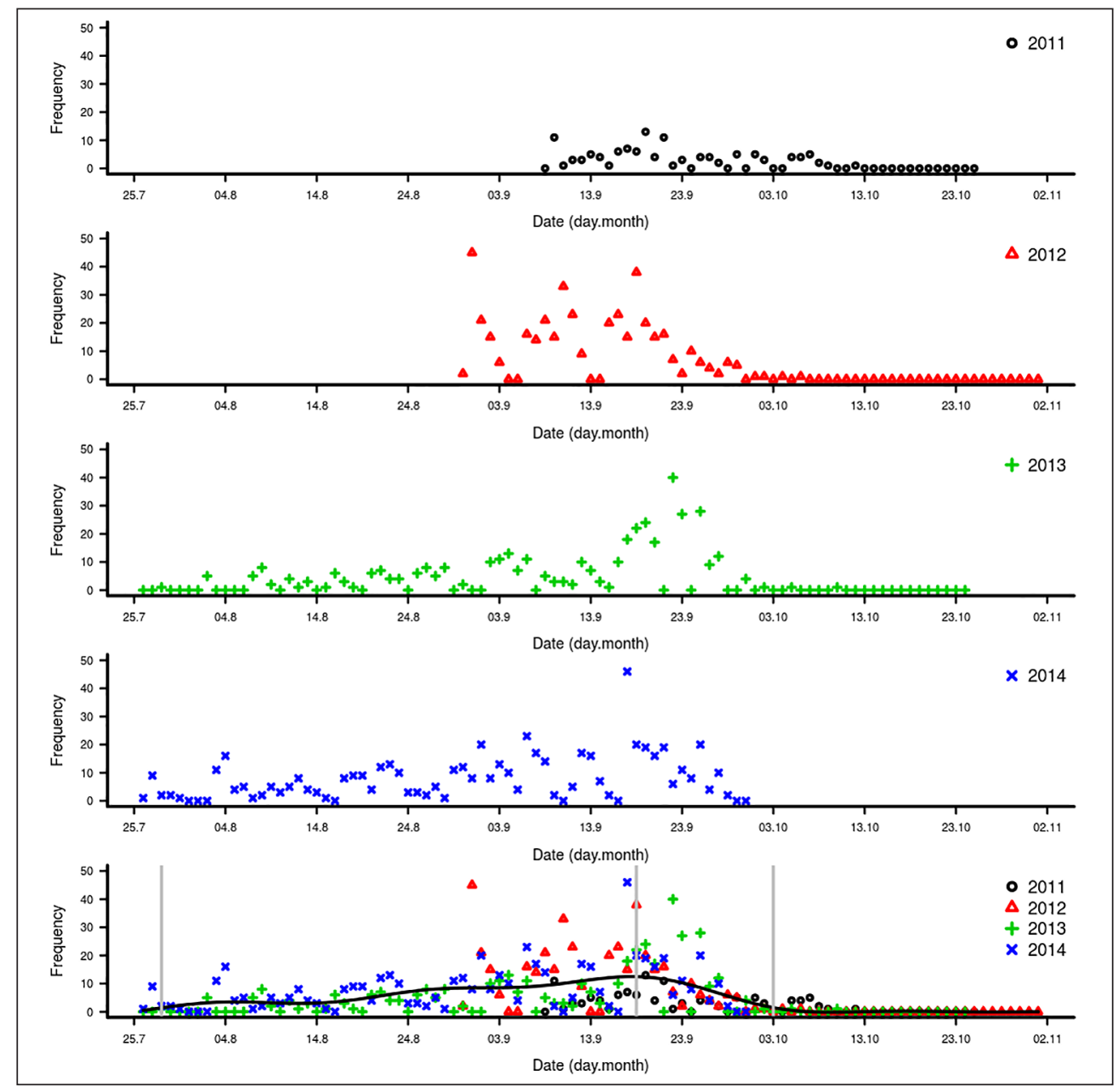

Figure 7. Daily number of ringed Dusky Warbler annually and pooled with the fitted smoothed curve. The vertical grey lines show the first, peak and last captures

7. ábra A gyűrűzött barna füzike napi gyakorisága éves bontásban és egyesítve a simított görbével. A függőleges szürke vonalak az első, a maximális és az utolsó megfogást mutatják

\section{Radde's Warbler}

The sixth most abundant species with 217 ringed individuals (Table 2). The migration took place between the $12^{\text {th }}$ and $64^{\text {th }}$ days. The peak of the migration wave was on the $49^{\text {th }}$ day. Of the ringed birds $13.8 \%$ have been recaptured, $58.3 \%$ within two days. An average of three days elapsed between the first and last capture, only two birds were retrapped after one week (Figure 8, Table 3). 


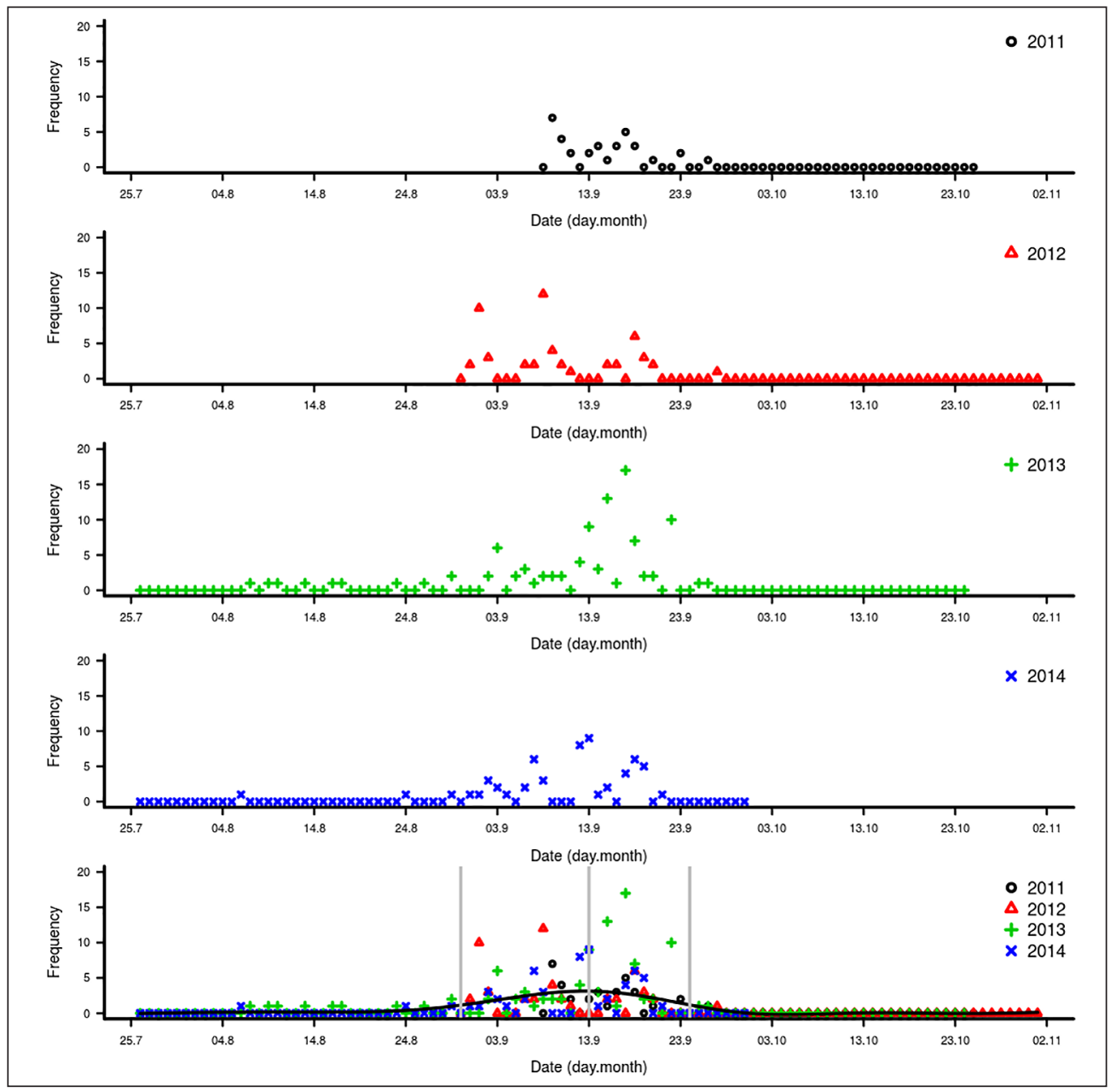

Figure 8. Daily number of ringed Radde's Warbler annually and pooled with the fitted smoothed curve. The vertical grey lines show the first, peak and last captures

8. ábra A gyürűzött vastagcsőrű füzike napi gyakorisága éves bontásban és egyesítve a simított görbével. A függőleges szürke vonalak az első, a maximális és az utolsó megfogást mutatják

\section{Two-barred Warbler}

Of all the studied species, this one was caught in the lowest numbers with 98 ringed individuals (Table 2). The migration took place between the $11^{\text {th }}$ and $67^{\text {th }}$ days. The peak of the migration wave was on the $30^{\text {th }}$ day. Of the ringed birds, $20.4 \%$ have been recaptured, $61.1 \%$ within two days. An average of 2.8 days elapsed between the first and last capture, only one bird was retrapped after one week (Figure 9, Table 3). 


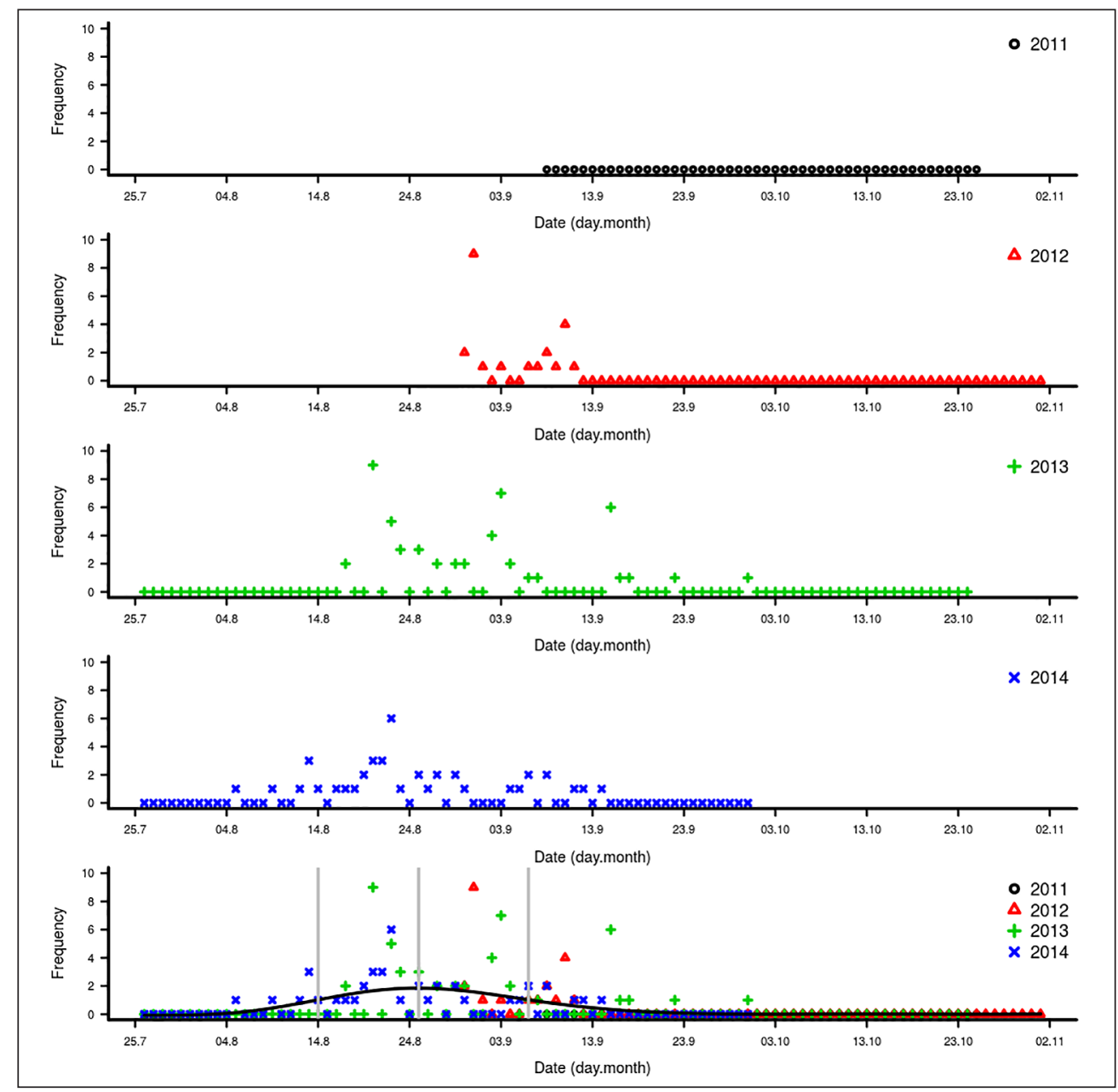

Figure 9. Daily number of ringed Two-barred Warbler annually and pooled with the fitted smoothed curve. The vertical grey lines show the first, peak and last captures

9. ábra A gyűrűzött szalagos füzike napi gyakorisága éves bontásban és egyesítve a simított görbével. A függőleges szürke vonalak az első, a maximális és az utolsó megfogást mutatják

\section{Discussion}

Most of the Siberian Passerines use the traditional autumn migration routes for the wintering sites in SE-Asia. However, many species have european, american and african occurrence data, far away from the usual migration routes and wintering sites, even in the opposite direction (Alerstam 1990). There have been many explanations developed for this in the last decades.

Based on the weather hypothesis, these species appear in Europe due to the Siberian anticyclones (Baker 1977, Howey \& Bell 1985, Baker \& Catley 1987, Elkins 1988). In favor of the hypothesis is the fact that the birds cannot compensate the effect of strong easterly winds (Liechti 2006), which can sweep them far away from their traditional distribution area 
by hundreds or thousands of kilometers (Elkins 1988). This hypothesis is confirmed by the captures of several individuals of different species. For example, 58 individuals of 13 species were detected in autumn 1975 in Britain, most of them on the Eastern coast (Baker 1977). There was a similar 'megadrift' in October 1982, when Pallas's, Dusky and Radde's Warbler (which have partially overlapped breeding areas) were observed in high numbers, in contrast with the Yellow-browed Warbler, which has more northerly breeding area, and the Artic and Greenish Warbler, which migrate earlier. These species occurred in lower numbers than the previous ones (Howey \& Bell 1985).

The number of observations about a given species shows large variation between the years (Rogers \& the Rarities Committee 2000, 2001, 2002, 2003, 2004, www.tarsiger.com, Fraser et al. 2005, 2006, Hudson \& the Rarities Committee 2007, 2008, 2009, 2010, 2011). For example, in 2013, 420, while in 2004, only 31 Yellow-browed Warbler individuals were observed in Finnland (www.tarsiger.com), due to the different intensity of cyclones (Baker 1977). An indirect confirmation of this hypothesis is that the number of yearly observations of species with different distribution areas and migration timing do not show correlation (Howey \& Bell 1985).

The argument against this hypothesis is that the effect of wind velocity should be different on animals of different sizes, although this could not be proven (Pfeifer et al. 2007). Also, European occurrence data of certain Siberian species overlap with their migration peaks, which indicates regularity (Harrop 2007). The number of Yellow-browed Warbler in Britain increased sharply from 1984. The annual average was 81 (27-182) between 1968-1983, and it was 382 (211739) between 1984-1998 (Fraser et al. 2000). The Siberian vagrants caught in North Ronaldsay (Great-Britain) were in better condition on arrival than the general run of commoner migrants. The reason for this might be that their build-up of fat reserves must have occurred during their migration (Woodbridge \& Duncan 1998).

On the basis of the reverse migration hypothesis, some individuals could occur in Europe due to genetic defect. In many cases, the migration direction of the observed birds differ by 180 degrees from the generally assumed direction (Rabøl 1969, 1976, Cottridge \& Vinicombe 1996, Thorup 1998). The distribution pattern of the occurrences falls in the shadow of the area covered by the correct migration route (vagrancy shadow) (Cottridge \& Vinicombe 1996). According to this hypothesis, in these birds, the inherited navigation mechanism is incorrect and the north - south pole or the spring - autumn programme is reversed (Gilroy \& Lees 2003, Pfeifer et al. 2007). In favor of the hypothesis is that the most of the European data of Siberian species overlap with their migration peaks and the flight distance correlates with the traditional migration distance (Harrop 2007). In addition, the Yellow-browed and Arctic Warbler with more northerly breeding areas occur in northern areas of Great Britain, compared to the Pallas's Leaf Warbler and Two-barred Warbler with more southerly breeding areas (Rabøl 1969).

In principle, the individuals that choose the wrong direction are supposed to be under strong selection, as they can get to areas, where the weather is unfavourable and the food supplies are scarce. However, it seems that some individuals that choose the wrong direction can survive the winter. Orientation experiments show that the migration direction of the survivors in spring is easterly, so they can get back with good chance to the original breeding area, and the wrong direction factor can also be inherited (Thorup 1998). The Yellow-browed Warbler has a stabile wintering population in Great Britain (Thorup 1998, Marchant 2002). 
This species had only a few observations before 1958, but between 1958-1985 it had already 2648 occurrences, and between 1986-2003 there were 9093 observations. The record was 853 observation data in one year. Similarly, the Pallas's Warbler had only a few observations before 1951 in Great Britain (Baker 1977), but between 1986-2003 it had already 1783 observation data with a 303 individuals year record (Dymond et al. 1989, Gilroy \& Lees 2003, Fraser \& Rogers 2006).

The argument against this hypothesis is that the yearly occurrences of most species show a big variability both in the British Isles and Scandinavia, despite the fact that the monitoring network is relatively stable, so the observations well approximate the actual numbers, or at least are proportionate (Rogers \& the Rarities Committee 2000, 2001, 2002, 2003, 2004, www.tarsiger.com, Fraser et al. 2005, 2006, Hudson \& the Rarities Committee 2007, 2008, 2009, 2010, 2011). Genetically, the only likely explanation is that in some years, many mutations arise, whereas in other years only a few, and these mutations are rare and their probability is constant (Freeman \& Herron 2001, Gilroy \& Lees 2003). In case of reverse migration, it could be expexted that the observations fall more-or-less at the same time within the distance from the breeding area. However, the data show that the birds appear earlier in the northern regions than in the southern ones, and the date of observations shifts to later towards the south. This time pattern is observable both in the Scandinavian countries and Great Britain and also in continental scale (September - Scandinavia, December - Canary Islands) (De Juana 2008).

The long-range dispersal hypotesis says that the occurrences not typical for the species may be in any direction (Philips 2000, Gilroy \& Lees 2003). With the analysis of capture-recapture data, observations on captive birds and radio telemetry, it can be detectable in some species that in the beginning of the migration, the birds can depart to any - even opposite - direction. These individuals migrate in the right direction only later (Berthold 1996). Dispersional movements have a main role in the discovery of new breeding areas and in the modification of the breeding area.

In favor of the hypothesis is that the Yellow-browed Warbler, the Olive-backed Pipit (Anthus hodgsoni), the Rustic Bunting (Emberiza rustica), the Little Bunting (E. pusilla) are regular visitors in Israel (Shirihai et al. 1996), while the Red-throated Thrush (Turdus ruficollis) has data from Northern-Europe, Israel, Egypt, Greece, France, Spain, Taiwan, Japan and Alaska (Gilroy \& Lees 2003).

One Yellow-browed Warbler was observed in 1999 in an Alaskan Island (Lehman 2000), it has been found in Senegal (De Juana 2008) and appeared from Iceland to Morocco, and from the Canary Islands to Kuwait (Snow \& Perrins 1998). One Lanceolated Warbler landed on a ship $110 \mathrm{~km}$ north of Bjørnøya in the Arctic Ocean (Lewington et al. 1991). These observations fall very far from the 'revers migration shadow'. The argument against this hypothesis is that the Yellow-browed and Arctic Warbler with more northerly breeding areas show different pattern in Great Britain than the Pallas's Leaf Warbler and Two-barred Warbler with more southerly breeding areas (Rabøl 1969). Maybe it is more important that the length of dispersal movements of long-distance migratory species is much shorter than the migratory distance itself (Berthold 1996).

Nowadays it is seems, that these birds are not really vagrants, but also regular migrants, which have Western-European or Western-African wintering sites. The high survival rate would explain that why increased the numnber of observed individuals of some species on the last decads (Gilroy \& Lees 2003, De Juana 2008), because of the 'west-orientating' genotypes are inherited. 
In favor of the hypothesis that going to south the number of spring observations are significantly increased. This also means that the birds use different migrations journays in spring and autumn (loop migration) (De Juana 2008).

A positive impact of climate change on range and population size could promote vagrancy, while the increasing use of such alternative migration flyways could provide adaptive advantages in a changing environment (Jiguet \& Barbet-Massin 2013).

From the foregoing it seems to be very difficult - may be impossible - generalize, coherent explanation for this phenomenon. For explanation several other parameters have to be tested for influence to the probability of the occurrences. For example, the number of individuals (unfortunately there are no good estimates of the Siberian species), the size of distribution area, the distance between the breeding and wintering sites, the migratory distance, the timing of migration, the length of the migration intervals, the variability of the European occurrences, the characteristics of the yearly autumn Siberian weather etc. The possibility of the detectation is greater, if the distribution area and the number of individuals are larger, the distance is shorter between the breeding and wintering sites (Pfeifer et al. 2007). There is lesser probability of the effects of the weather anomalies, if the migration of the individuals is faster and in species-level is narrow interval than a species with slower migration and broader interval.

The studies species have large distribution area, expect the Yellow-browed Warbler and Twobarred Warbler which have very large distribution area (BirdLife International 2013), but in the previous category there are big differences. The average migration length is $1500-3000 \mathrm{~km}$, while the distance between the breeding area and Western-Europe is $2000-6000 \mathrm{~km}$. The average distance between the studied site and the northern border of the breeding area is $800-2000 \mathrm{~km}$ (Table 1).

As mentioned above, the occurrence of Siberian species in Europe cannot be explained by any of the hypothesis alone, since the distribution area, timing of migration and intervals of the species differ. The observations of species which have breeding populations in Europe are most likely explained by dispersal movements. In case of the other species, it cannot be excluded that reverse migration takes place. This suits the occurrence data of the Yellow-browed Warbler, whereas the large annual differences might be explained by differences in the intensity of weather conditions.

Climate change will surely have an impact on the distribution areas of the species, but at present, weather anomalies might be a better explanation for the occurrence of Siberian vagrants in Europe.

The expected increase in the number of records, a comparison of the results of studies along the migration routes and the examination of the orientation capabilities of vagrants in Europe will help to understand the observed patterns.

\section{Acknowledgements}

We want to thank the staff of Muraviovka Park, the Moscow Bird Ringing Centre as well as all helpers and sponsors of the Amur Bird Project. LB would like to thank his sponsors, so the local government of Kevermes, the contractors of Kevermes and the Campus Hungary Studentship that allowed the research. Many thanks also to Erna Borbáth for the help in the English translation and Jozsef Vuts the correction. 


\section{References}

Alerstam, T. 1990. Bird migration. - Cambridge University Press

Baker, K. 1977. Westward vagrancy of Siberian Passerines in autumn 1975. - Bird Study 24: 232242.

Baker, J. K. \& Catley, G. P. 1987. Yellow-browed Warblers in Britain and Ireland, 1968-85. - British Birds 80(3): 93-109.

Berthold, P. 1996. Control of bird migration. - Chapman \& Hall, London

BirdLife International 2013. BirdLife data zone. (www.birdlife.org/datazone/home)

Brazil, M. 2009. Birds of East Asia. - Christopher Helm, London

Carey, G. J., Chalmers, M. L., Diskin, D. A., Kennerley, P. R., Leader, P. J., Leven, M. R., Lewthwaite, R. W., Melville, D. S., Turnbull, M. \& Young, L. 2001. The avifauna of Hong Kong. Hong Kong Birdwatching Society, Hong Kong

Cottridge, D. M. \& Vinicombe, K. 1996. Rare birds in Britain and Ireland. A photographic record. Collins, London

Cramp, S. \& Brooks, D. J. 1992. The birds of the Western Palearctic. Vol. VI. Warblers. - Oxford University Press, Oxford

De Juana, E. 2008. Where do Pallas's and Yellow-browed Warblers (Phylloscopus proregulus, $P h$. inornatus) go after visiting Northwest Europe in autumn? An Iberian perspective. - Ardeola 55(1): 13-25.

De Sante, D. F. 1983. Vagrants: when orientation or navigation goes wrong. - Point Reyes Bird Observatory Newsletter 61: 12-16.

Duckworth, J. W. 2007. Seasonality of the Arctic Warbler Phylloscopus borealis in northern Korea, with refutation of previous assumptions of Korean breeding. - Ardea 95(1): 105-113. DOI: 10.5253/078.095.0112

Dymond, J. N., Fraser, P. A. \& Gantlett, S. J. M. 1989. Rare birds in Britain and Ireland - T \& AD Poyser, Calton

Elkins, N. 1988. Weather and bird behaviour. - Poyser, Calton

Folvik, A. 1992. Norwegian records of Yellow-browed Warbler Phylloscopus inornatus. Fauna Norvegica Series C Cinclus 15: 31-36.

Fraser, P. A., Lansdown, P. G. \& Rogers, M. J. 2000. Report on scarce migrant birds in Britain in 1998. - British Birds 93: 588-641.

Fraser, P. A., Rogers, M. J. \& the Rarities Committee 2005. Report on rare birds in

Great Britain in 2005: Part 2: Passerines. - http:// www.bbrc.org.uk/resources
Fraser, P. A. \& the Rarities Committee 2006. Report on rare birds in Great Britain in 2006, Part 2. Passerines. - http://www.bbrc.org.uk/resources

Freeman, S. \& Herron, J. C. 2001. Evolutionary analysis. - Prentice Hall, New Yersey

Gilroy, J. J. \& Lees, A. C. 2003. Vagrancy theories: are autumn vagrants really reverse migrants? British Birds 96: 427-438.

Halmos, G., Kováts, L., Vadász, Cs. \& Csörgő, T. 2000. A himalájai füzike (Phylloscopus humei) vonulása a Mongol Altájban [The autumn migration of the Hume's Yellow-browed Warbler (Phylloscopus humei) in the Altai-Mountains, Mongolia]. - Ornis Hungarica 10: 115-121. (in Hungarian with English Summary)

Hadarics, T. \& Zalai, T. (eds.) 2008. Magyarország madarainak névjegyzéke. Nomenclator Avium Hungariae. An annotated list of the birds of Hungary. - Magyar Madártani és Természetvédelmi Egyesület, Budapest

Harrop, A. J. A. 2007. Eastern promise: the arrival of far-eastern passerine vagrants in autumn. - British Birds 100: 105-111.

Heim, W., Smirenski, S. M., Siegmund, A. \& Eidam, F. 2012. Results of an autumnal bird ringing project at Muraviovka Park/Amur region in 2011. Avian Ecology and Behaviour 21: 27-40.

Heim, W. 2014. Birds at Muraviovka Park 20112013: Results of the Amur Bird Project. Technical Report http://www.researchgate.net/ publication/281616935_Amur_Bird_Project Report_2011-2013

Heim, W. \& Smirenski, S. M. 2013. The Amur Bird Project at Muraviovka Park in Far-eastern Russia. - Birding Asia 19: 31-33.

Howey, D. H. \& Bell, M. 1985. Pallas's Warbler and other migrants in Britain and Ireland in October 1982. - Bitish Birds 78: 381-392.

Hudson, N. \& the Rarities Committee 2007. Report on rare birds in Great Britain in 2007. - http:// www.bbrc.org.uk/resources

Hudson, N. \& the Rarities Committee 2008. Report on rare birds in Great Britain in 2008. - http:// www.bbrc.org.uk/resources

Hudson, N. \& the Rarities Committee 2009. Report on rare birds in Great Britain in 2009. - http:// www.bbrc.org.uk/resources

Hudson, N. \& the Rarities Committee 2010. Report on rare birds in Great Britain in 2010. - http:// www.bbrc.org.uk/resources

Hudson, N. \& the Rarities Committee 2011. Report on rare birds in Great Britain in 2011. - http:// www.bbrc.org.uk/resources 
Jiguet, F. \& Barbet-Massin, M. 2013. Climate change and rates of vagrancy of Siberian species to Europe. - Ibis 155: 194-198. DOI: 10.1111/ ibi. 12001

Katti, M. \& Price, D. T. 2003. Latitudinal trends in body size among over-wintering leaf warblers (genus Phylloscopus). - Ecography 26(1): 6979. DOI: 10.1034/j.1600-0587.2003.03264.x

Krüger, T. \& Dierschke, J. 2004. The occurrence of Yellow-browed Warbler Phylloscopus inornatus in Germany. - Vogelwelt 125: 41-52.

Lehman, P. 2000. First record of Yellow-browed Warbler Phylloscopus inornatus in North America. - Western Birds 31: 57-60.

Lewington, I., Alström, P. \& Colston, P. 1991. Field guide to the rare birds of Britain \& Europe. Harper Collins

Liechti, F. 2006. Birds: blowin' by the wind? Journal of Ornithology 147(2): 202-211. DOI 10.1007/s10336-006-0061-9

Marchant, J. H. 2002. Yellow-browed Warbler, Phylloscopus inornatus. - In: Werham, C. V., Toms, M. P., Marchant, J. H., Clark, J. A., Siriwardena, G. M. \& Baillie, S. R. (eds.) The migration atlas: movements of the Birds of Britain and Ireland. Poyser, London

Marchetti, K., Price, D. T. \& Richman, A. 1995. Correlates of wing morphology with foraging behaviour and migration distance in the genus Phylloscopus. - Journal of Avian Biology 26(3): 177-181. DOI: $10.2307 / 3677316$

Nisbet, I. C. T. 1967. Migration and moult in Pallas's Grasshopper Warbler. - Bird Study 14(2): 96103. DOI: $10.1080 / 00063656709476150$

Pfeifer, R., Stadler, J. \& Brandl, R. 2007. Birds from the Far-East in Central-Europe: a test of the reverse migration hypothesis. - Journal of Ornithology 148: 379-385. DOI: $10.1007 /$ s10336007-0140-6

Phillips, J. 2000. Autumn vagrancy: "Reverse migration" and migratory orientation. Ringing \& Migration 20(1): 35-38. DOI: $10.1080 / 03078698.2000 .9674226$

Rabøl, J. 1969. Reversed migration as the cause of westward vagrancy by four Phylloscopus warblers. - British Birds 62: 89-92.

Rabøl, J. 1986. British rarities in a foreign perspective. - British Birds 79(6): 300-302.

Raess, M. 2008. Continental efforts: migration speed in spring and autumn in an inner-Asian migrant. - Journal of Avian Biology 39(1): 13-18. DOI: 10.1111/j.2007.0908-8857.04300.x

$\mathrm{R}$ Core Team 2015. R: A language and environment for statistical computing. R Foundation for
Statistical Computing, Vienna, Austria. https:// www.R-project.org/.

Rogers, M. J. \& the Rarities Committee 2000. Report on rare birds in Great Britain in 2000. With comments by John McLoughlin and Jimmy Steele. http://www.bbrc.org.uk/resources

Rogers, M. J. \& the Rarities Committee 2001. Report on rare birds in Great Britain in 2001. With comments by John McLoughlin and Jimmy Steele. http://www.bbrc.org.uk/resources

Rogers, M. J. \& the Rarities Committee 2002. Report on rare birds in Great Britain in 2002. - http:// www.bbrc.org.uk/resources

Rogers, M. J. \& the Rarities Committee 2003. Report on rare birds in Great Britain in 2003. - http:// www.bbrc.org.uk/resources

Rogers, M. J. \& the Rarities Committee 2004. Report on rare birds in Great Britain in 2004. - http:// www.bbrc.org.uk/resources

Shirihai, H., Dovrat, E., Christie, D. A. \& Harris, A. 1996. The birds of Israel. - London, Academic Press

Svensson, L. 1992. Identification guide to European passerines. $-4^{\text {th }}$ revised and enlarged edition, Svensson, Stockholm

Thorup, K. 1998. Vagrancy of Yellow-browed Warbler Phylloscopus inornatus and Pallas's Warbler Ph. proregulus in north-west Europe: Misorientation on great circles? - Ringing \& Migration 19: 7-12. DOI: 10.1080/03078698.1998.9674155

Thorup, K. 2004. Reverse migration as a cause of vagrancy: Capsule reverse migration in autumn does not occur to the same degree in all species of migrants, but is related to migratory direction. - Bird Study 51: 228-238. DOI: 10.1080/00063650409461358

Williams, M. D. 2000. Autumn bird migration at Beidaihe, 1986-1990. - Beidaihe International Birdwatching Society, Hong Kong

Williamson, K. 1959. The September drift-movements of 1956 and 1958. - British Birds 53: 334-377.

Wood, S. N. 2006. Generalized Additive Models: An Introduction with R. Chapman and Hall/CRC

Woodbridge, K. F. \& Duncan, A. E. 1998. Condition of passerine vagrants on North Rolandsay as first capture using fat score. - Ringing \& Migration 19: 5-6. DOI: 10.1080/03078698.1998.9674154 www.birding.hu www.netfugl.dk www.rombird.ro www.tarsiger.com 